\title{
Loose Seed Implant
}

National Cancer Institute

\section{Source}

National Cancer Institute. Loose Seed Implant. NCI Thesaurus. Code C105732.

A radioactive implant consisting of individual pellets. 